\title{
Examining Community Trust to the Audit Board of the Republic of Indonesia
}

\author{
Penta Widyartati ${ }^{1}$ \\ Doctorate Student of Accounting Programme \\ Diponegoro University \\ Semarang, Indonesia \\ ${ }^{1}$ pentawidyartati@students.undip.ac.id
}

\author{
Tri Jatmiko Wahyu Prabowo \\ Doctorate Lecturer of Accounting Programme \\ Diponegoro University \\ Semarang, Indonesia
}

\begin{abstract}
The second term of Audit Results Summary Report (IHPS) of Audit Board of the Republic of Indonesia or Badan Pemeriksa Keuangan (BPK) concluded that the implementation of commercial bank supervision by OJK for 2017-2019 has met the criteria with exceptions. The exception occurred in the incomplete supervision for several banks. This study aims to determine whether the negative opinion of the BPK has been responded by investors. The research was conducted by comparing the volatility of banks that are excepted by the BPK with the banks that are not excepted by the BPK. The sample of banks that are excepted by the BPK was represented by 4 banks and the banks that are not excepted by the BPK were represented by 31 Banks. The test was carried out using a nonparametric independence $t$ test. The test results show that there is a significant difference between the volatility of banks that are excepted by the BPK and banks that are not excepted by the BPK. The existence of this significant difference provides empirical evidence that investors respond to the negative opinion of BPK. This response shows that the BPK's opinion is trusted and is considered to provide adequate information for investors.
\end{abstract}

Keywords: supervision, investor response, volatility

\section{INTRODUCTION}

Board of the Republic of Indonesia is an Indonesian institution that has the authority to examine the management and responsibility of state finances. In the 1945 Constitution, the BPK is an independent and free institution. This statement is stated in the 1945 Constitution. BPK members are elected by Indonesian legistilative assembly and inaugurated by the President.

As the Audit Board, BPK's task is to examine financial management and responsibility of the Central Government, Regional Government, Bank Indonesia, other State Institutions, state-owned enterprise, Public Service institution, provincially/municipally-owned corporation, and all other institutions that manage state finances. The results of the examination of the management and accountability of state finances are then reported to the Regional Representative Council Dewan Perwakilan Daerah (DPD) or Regional Representative Council, Dewan Perwakilan Rakyat (DPR) or the People's Representative Council, and the Dewan Perwakilan Rakyat Daerah (DPRD) or Regional People's Representative Council. The results of the examination must also be reported to the President, Governor and Regent / Mayor.

In carrying out its duties, the BPK has the authority to determine the object of the examination, plan and carry out the audit. The BPK also has the authority to determine the time and method of examination and to prepare and present reports.

In carrying out its duties, the BPK provides its work report as outlined in the Audit Result Summary which is submitted twice a year. These reports are the IHPS I issued in September and the IHPS II issued in March of the following year.

As an independent institution that examines the performance of government institutions, of course this institution must be an institution that is trusted by the public. This trust indicator can be measured by the presence or absence of community response when the institution publishing information. Information provided by an independent audit agency is about the auditor's opinion on the object of the examination.

Research on public trust in audit institutions has been conducted by several researchers. The study conducted in China failed to find evidence that modified audit opinions had significant informational value for Chinese investors, despite regulatory changes [1]. However, when partitioning the sample by year, there is weak evidence of share price responses to the modified audit opinion in 2003. An examination of the impact of different types of audit opinion shows no consistent results.

Different results are shown in research that this analysis shows that the audit report under investigation contains information for investment decisions [2]. In particular, the qualifications stated in the audit report have a negative effect on share prices. In addition, it is also shown that Unqualified Opinion with an emphasis on material paragraphs regarding business continuity uncertainty or financial distress has a positive effect on stock prices.

The same results were written in a study that companies receiving modified opinion had lower earnings persistence than companies receiving unqualified opinion, and that the level of earnings persistence varied among modification types [3]. This reseach conduct in Thailand. They find that companies with qualified or disclaimed opinions have lower earnings persistence than firms that receive unqualified opinions. However, in the study, there was no difference in earnings 
persistence between companies that received the qualifications. This analysis reveals that there is information in several types of modified opinions regarding the quality of earnings. Companies that receive the qualification for the scope of business continuity have lower earnings persistence.

From this research gap, we are interested in examining public trust in the BPK as a financial audit agency. The variable studied was the volatility of stock prices, stock price volatility can occur due to information received by investors. Stock price volatility is an indicator in assessing stock risk. Shares that have price fluctuations or high volatility are high risk stocks. High volatility means prices go up. high rapidly then suddenly drops rapidly, giving rise to a huge difference between the lowest and the highest prices at any given time.

In this study, volatility is used as a variable to show investor response to information provided by the BPK regarding the performance of the institution that manages state finances, namely the Otoritas Jasa Keuangan(OJK)or Financial Services Authority. OJK is the authority whose function to implement an integrated regulatory and supervisory system for all activities in the financial services sector. Among others, by carrying out regulatory and supervisory duties on financial service activities in the banking sector. To carry out these tasks, OJK has regulatory and supervisory authority regarding bank institutions, bank healthy, bank prudential aspects and bank examiners (IHPS II, 2019). In the IHPS II report published in March 2020, BPK said that the implementation of commercial bank supervision by OJK for 2017-2019 has met the criteria with exceptions. Significant problems found were related to weaknesses in internal control and non-compliance with statutory provisions. Supervision at several individual banks is not fully in accordance with the provisions, among others, Bank BTN, Bank Yudha Bhakti, Bank Mayapada, Bank Papua, Bank Banten, Bank Bukopin, and Bank Muamalah Indonesia. This disclosure is interesting, because during a pandemic that presses the banking industry like this, the BPK actually submits a report that can cause the public to distrust Bank institutions. Public distrust of bank institutions that are exempted from IHPS can be seen from the reaction of investors to the trading of the shares concerned. Investors' reactions can be seen from the movement of stock trading which causes stock prices to fluctuate.

Ha: there is a significant difference in volatility of exceptioned bank an unexeptioned bank.

\section{METHODS}

The method used in this study is the non-parametric independent $t$ test. Non-parametric testing is carried out because the data are not normally distributed. This test is carried out by comparing the volatility of bank share prices mentioned in the exception by the BPK with the volatility of bank share prices not mentioned in the exception. The data used are daily data after the publication date of the BPK Audit Result Summary Report (IHPS II), are April, May and June 2020. The research population is banks listed on the IDX. The sampling method was purposive sampling. The sample criteria are stocks which are actively traded shares on the IDX and have complete data from April to June 2020. From these criteria, the sample for banks in the exception is 4 banks, are
Bank BTN, Bank Mayapada, Bank Yudha Bhakti, and Bank Bukopin. Meanwhile, the sample for banks that are not included in the exception is 31 banks. Data obtained from yahoo finance.com pag.

\section{RESULTS AND DISCUSSION}

The results of the non-parametric independent $t$ test obtained the following results:

TABLE 1. RANKS

\begin{tabular}{llccc}
\hline & Criteria & N Rank & Rean & $\begin{array}{c}\text { Sum of } \\
\text { Ranks }\end{array}$ \\
\hline Volatility & Exceptioned & 204 & 1054,69 & 215157,00 \\
& & Unexceptione & 1621895,17 & 1451068,00 \\
& & & \\
& & Total & 1825 & \\
& & &
\end{tabular}

From the SSPS output, it proved that there is an average difference between the excluded criteria and the non-excluded criteria in the IHPS II report. The average share price volatility of banks that were excluded in IHPS II was higher than the volatility of share prices of banks that were not excluded in IHPS II. This difference is reinforced by the following table which shows the significance of the differences.

\section{TABLE 2. TEST STATISTICSA}

\begin{tabular}{ll}
\hline & Volatility \\
\hline Mann-Whitney U & 136437,000 \\
Wilcoxon W & 1451068,000 \\
Z & $-4,076$ \\
Asymp. Sig. (2-tailed) &, 000 \\
\hline a. Grouping Variable: Kriteria &
\end{tabular}

From the non-parametric independent $t$ test, it was found that there was a significant difference between the volatility of the banks that were excluded and those that were not. This shows that there is an investor response after announcing the weakness of control at these banks.

Investors can respond to high volatility as stocks that have a high risk. In stock trading, some investors avoid high-risk stocks [4]. But for short-term investors, this is seen as providing quick returns. Fast fluctuations indicate high risk, which at the same time can provide a high return or what is known as high risk high return. But volatility that is too high also poses a risk to the listed company [5] . Because if there is a fluctuation that is too high and shows an unreasonable movement, the shares concerned face the risk of suspension or temporary suspension of trading on the stock exchange for an indefinite period of time [6]. 
The companies that go public will have an obligation to submit quality financial reports [7]. Quality financial reports are financial reports that have been audited by a public accounting firm so that the timeliness of the presentation and the fairness of the financial statements is not in doubt. Furthermore, investors will respond to the earnings information contained in the financial statements [4]. This response is indicated by changes in the price of the shares concerned. Investors' response to earnings information as indicated by the stock price will help investors make expectations of future profits because the stock price reflects how much return the investor will get.

The ability to predict earnings is a parameter or coefficient of the regression results between stock returns and changes in annual earnings developed from the. The profit used in this study is earnings per share (EPS). EPS is obtained by dividing operating profit before all extraordinary items by the number of shares. Furthermore, users of financial statements will have more confidence in the results of audits conducted by professional auditors from The Big Four. The audit quality of the financial statements is measured by the ability of users of financial statements to anticipate the benefits that will be obtained in the future, which will be much higher if the financial statements are audited by one of the public accounting firms listed on The Big Four. It seems clear that the financial statements audited by The Big Four can provide a clear picture for investors to predict future earnings.

Companies that go public will have an obligation to submit quality financial reports. Quality financial reports are financial reports that have been audited by a public accounting firm so that the timeliness of the presentation and the fairness of the financial statements is not in doubt. The financial report will be published for the benefit of investors, creditors, government and the public [8]. Financial statements are important information for investors in making investment decisions [9]. Information disclosed in annual reports can be in the form of accounting information, namely information relating to financial reports and non-accounting information, namely information that is not related to financial statements [10]

Audit opinion has an effect on changes in stock prices [11]. Stock prices are a reflection of the company's condition, companies with good prospects will have high stock prices. Therefore, investors are very concerned about the stock price of the company they are buying [12]. The main objective of investors is to get profit from this investment [13]. The profits obtained by investors from this share investment can come from distributed company profits or dividends, and an increase or decrease in stock prices. Increase or decrease in stock prices is influenced by many factors, there are internal factors and there are also external factors [14]. External factors that affect market prices such as economic conditions, government policies, inflation, political conditions, etc. Internal factors that influence share prices such as management decisions, internal management policies and company performance [15]. Companies cannot control external factors because these factors occur outside the company. can control internal factors so that their share price does not fall. One way to control internal factors is through company performance.
Audit opinion in the financial statements is conducted by different auditors of public accounting firms [16] . A quality public accounting firm is considered to have high expertise to detect material misstatements contained in financial statements. KAP size affects the quality of opinion stated by auditors [17]. KAP size reflects the quality of audit opinion that can affect investors in Stock investment. The size of KAP partially has a positive effect on stock prices [18]. KAP size has a strong relationship to stock prices, because big four KAP in general can conduct a more professional audit than non big four KAP The share price is also affected by the level of company profit. Because if a company's profit increases, the company's stock price will also increase or in other words, ROA affects the stock price. ROA affects stock prices that ROA has an effect in predicting stock prices. ROA has a significant effect on stock prices. In addition, the level of company liquidity can affect stock prices. The current ratio has a partial effect on stock prices. predict stock prices. The current ratio has a positive and significant effect on stock prices.

In connection with the auditor's opinion, in this case the BPK, that the audit opinion is the auditor's conclusion on the audit process that has been carried out and the opinion regarding the fairness of the contents of the company's financial statements [19]. Information will have meaning for investors if the information causes investors to make transactions in the capital market, all these transactions are reflected in changes in share prices [20]. The auditor's opinion is important information, making the auditor's opinion will affect the stock price in the capital market [21]. Auditor's opinion is a source of information for parties outside the company as a guide for decision making. For potential investors, the auditor's opinion on the financial statements is one of the important considerations in making investment decisions [22]. Information published as an announcement will provide a signal for investors in making investment decisions [23]. If the announcement contains a positive value, it is expected that the market will react when the announcement is received by the market. In signal theory, it is explained that when the information is announced and all market players have received the information, market participants first interpret and analyze the information as a good signal (good news) or a bad signal (bad news) [24]. If the announcement is a good signal for investors, there will be a change in share trading volume. This is supported by agency theory which states that there is a relationship or contract between the manager (agent) and the investor (principal). A good contract between investors and managers is a contract that is able to explain what the manager must do in managing the invested funds and sharing returns between managers and investors [25].

Financial reports contain earnings information that are very useful for users of financial statements, especially investors [26]. If investors want to invest their funds in a company, investors will see the company's performance, which is reflected in how much profit the company makes in one accounting period [27]. Companies that report positive profit on the profit / loss statement mean that the revenue the company earns is greater than the expenses it incurs. Likewise, the company that reports negative profit means that the expenses incurred during the company's operations are greater 
than the income it earns [28]. Companies that report positive profits are expected to have the ability to continue to be able to generate positive profits and further increase their profits in the future so that they can help investors to predict the profits they will get in the future [29].

An investor's ability to predict future profits is the ability of an investor to make speculations on the profits he will get in the future [30]. An investor can predict the profit he will get by observing the profit information about the investment he has made. Earnings information will be reflected in the stock price, which then from the stock price investors can calculate stock returns and profit growth. Return on shares and profit growth are related. If the stock return is positive, then the profit growth for that period will also be positive [31][32]. The relationship between stock returns and positive profit growth can help investors predict how much profit they will get in the future[33][34][35]. Furthermore, investors will use all the information available in the market to analyze the company's performance and predict earnings.

In calculating the results and prospects of the company, investors need an assessment from the services of an accountant to ensure that the company's financial statements contain relevant information and have high audit quality[36][37][38]. High audit quality is indicated by the auditor's ability to detect material misstatements and manipulation practices that may be contained in the company's financial statements.Companies that have started presenting financial reports with high audit quality are expected to help the market anticipate changes in earnings for the better for companies whose financial statements have been audited [39][40][41]. The goal is for investors to anticipate future returns for up to two years for companies whose financial statements are being audited. This means that audit quality produces quality earnings information, namely earnings information that is timely reporting and contains an element of fairness in its presentation so as to increase the level of investors' predictions of future earnings.

\section{CONCLUSION}

There is a significant difference between the volatility of the banks that are excluded and that are not. The auditor's opinion, in this case the BPK, will influence investors. The auditor's opinion is important information, making the auditor's opinion will affect the stock price in the capital market. Auditor's opinion is a source of information for parties outside the company as a guide for decision making. For potential investors, the auditor's opinion on the financial statements is one of the important considerations in making investment decisions.

\section{ACKNOWLEDGMENT}

The author would like to express his gratitude to Diponegoro University in particular for the accounting doctoral program which has provided various knowledge provisions both in terms of analysis and training in the preparation of good papers.

\section{REFERENCES}

[1] R. Czernkowski, W. Green, and Y. Wang, "The value of audit qualifications in China," Manag. Audit. J., 2010.

[2] G. Ianniello and G. Galloppo, "Stock market reaction to auditor opinions-Italian evidence," Manag. Audit. J., 2015.

[3] T. Vichitsarawong and S. Pornupatham, "Do audit opinions reflect earnings persistence?," Manag. Audit. J., 2015.

[4] S. A. M. Al-Rjoub and H. Azzam, "Financial crises, stock returns and volatility in an emerging stock market: the case of Jordan," J. Econ. Stud., 2012.

[5] D. Mo, N. Todorova, and R. Gupta, "Implied volatility smirk and future stock returns: evidence from the German market," Manag. Financ., 2015.

[6] H. Moalla, "Audit report qualification/modification," J. Account. Emerg. Econ., 2017.

[7] G. He, L. Bai, and H. M. Ren, "Analyst coverage and future stock price crash risk," J. Appl. Account. Res., 2019.

[8] R. Kumar, "Risk, uncertainty and stock returns predictability-a case of emerging equity markets," J. Financ. Econ. Policy, 2018.

[9] K. Ittonen, "Market reactions to qualified audit reports: research approaches," Account. Res. J., 2012.

[10] A. Lee, C. Y. Lim, and T. C. Zhang, "Cross-quarter differential market reactions," Pacific Account. Rev., 2016.

[11] S. Abdallah, "External auditor type, discretionary accruals and investors' reactions," J. Account. Emerg. Econ., 2018.

[12] J. P. S. Ballesta and E. García-Meca, "Audit qualifications and corporate governance in Spanish listed firms," Manag. Audit. J., 2005.

[13] C. Gaganis and F. Pasiouras, "A multivariate analysis of the determinants of auditors' opinions on Asian banks," Manag. Audit. J., 2007.

[14] A. Habib and H. J. Huang, "Abnormally long audit report lags and future stock price crash risk: evidence from China," Int. J. Manag. Financ., 2019.

[15] A. Habib, "A meta-analysis of the determinants of modified audit opinion decisions," Manag. Audit. J., 2013.

[16] G. Liu and J. Sun, "Share price response to the SEC administrative proceedings against Chinese auditors," Manag. Audit. J., 2019.

[17] M. Maffei, C. Fiondella, C. Zagaria, and A. Zampella, "A multiple discriminant analysis of the auditor's going concern opinion: the case of audit opinions in Italy," Meditari Account. Res., 2020.

[18] L. Mbarek and D. M. Hmaied, "Bank informational opacity: evidence from the Tunisian stock market," J. Financ. Regul. Compliance, 2012.

[19] Q. Tang, H. Chen, and Z. Lin, "How to measure country-level financial reporting quality?," J. Financ. Report. Account., 2016.

[20] S. Y. Park and H.-Y. Park, "Do statutory internal auditors influence stock price crash risk? Firm-level evidence from Korea," Manag. Audit. J., 2019.

[21] B. Sarath, "Audit quality within adverse selection markets," Asian Rev. Account., 2016.

[22] M. Sri and S. Solimun, "The relationship between audit quality and risk taking toward value creation in Indonesia," J. Account. Emerg. Econ., 2019.

[23] C. P. Cullinan, F. Wang, B. Yang, and J. Zhang, "Audit opinion improvement and the timing of disclosure," $A d v$. Account., vol. 28, no. 2, pp. 333-343, 2012.

[24] M. C. Diaz, "Assembling the opinion: An active learning exercise for audit students," J. Account. Educ., vol. 34, pp. 30-40, 2016.

[25] M. Tsipouridou and C. Spathis, "Audit opinion and earnings management: Evidence from Greece," in Accounting Forum, 2014, vol. 38, no. 1, pp. 38-54.

[26] M. Cipriano, E. L. Hamilton, and S. D. Vandervelde, "Has the lack of use of the qualified audit opinion turned it into the 'Rotten Kid' threat?," Crit. Perspect. Account., vol. 47, pp. 26-38, 2017. 
[27] Z. Xie, C. Cai, and J. Ye, "Abnormal audit fees and audit opinionFurther evidence from China's capital market," China J. Account. Res., vol. 3, pp. 51-70, 2010.

[28] C. Li, K. K. Raman, L. Sun, and D. Wu, "The effect of ambiguity in an auditing standard on auditor independence: Evidence from nonaudit fees and SOX 404 opinions," J. Contemp. Account. Econ., vol. 13, no. 1, pp. 37-51, 2017.

[29] J. Legoria, G. Rosa, and J. S. Soileau, "Audit quality across non-audit service fee benchmarks: Evidence from material weakness opinions," Res. Account. Regul., vol. 29, no. 2, pp. 97-108, 2017.

[30] D. Pei and P. A. Hamill, "Do modified audit opinions for Shanghai listed firms convey heterogeneous information?," J. Int. Accounting, Audit. Tax., vol. 22, no. 1, pp. 1-11, 2013.

[31] Z. Zhao, "Address forms in Chinese audit opinions," China J. Account. Res., vol. 7, no. 4, pp. 247-261, 2014.

[32] J. Chen, D. Cumming, W. Hou, and E. Lee, "Executive integrity, audit opinion, and fraud in Chinese listed firms," Emerg. Mark. Rev., vol. 15, pp. 72-91, 2013.

[33] W. G. Blacconiere and M. L. DeFond, "An investigation of independent audit opinions and subsequent independent auditor litigation of publicly-traded failed savings and loans," J. Account. Public Policy, vol. 16, no. 4, pp. 415-454, 1997.
[34] K.-W. Lai, "Audit report lag, audit fees, and audit quality following an audit firm merger: Evidence from Hong Kong," J. Int. Accounting, Audit. Tax., vol. 36, p. 100271, 2019.

[35] Y. G. Shan, I. Troshani, and A. Tarca, "Managerial ownership, audit firm size, and audit fees: Australian evidence," J. Int. Accounting, Audit. Tax., vol. 35, pp. 18-36, 2019.

[36] M. G. Shuraki, O. Pourheidari, and M. Azizkhani, "Accounting comparability, financial reporting quality and audit opinions: evidence from Iran," Asian Rev. Account., 2020.

[37] F. Imen and J. Anis, "The moderating role of audit quality on the relationship between auditor reporting and earnings management: empirical evidence from Tunisia," EuroMed J. Bus., 2020.

[38] R. A. Simamora and H. Hendarjatno, "The effects of audit client tenure, audit lag, opinion shopping, liquidity ratio, and leverage to the going concern audit opinion," Asian J. Account. Res., 2019.

[39] P. Tahinakis and M. Samarinas, "The incremental information content of audit opinion," J. Appl. Account. Res., 2016.

[40] F. Hu, J. Stewart, and W. Tan, "CEO's political connections, institutions and audit opinions," Pacific Account. Rev., 2017.

[41] S. Yao, L. Pan, and Z. Zhang, "Does environmental disclosure have an auditing effect?," Manag. Audit. J., 2019. 